\title{
Species and stock identification of prey consumed by endangered southern resident killer whales in their summer range
}

\author{
M. Bradley Hanson ${ }^{1, *}$, Robin W. Baird ${ }^{2}$, John K. B. Ford ${ }^{3}$, Jennifer Hempelmann-Halos ${ }^{1}$, \\ Donald M. Van Doornik ${ }^{4}$, John R. Candy ${ }^{3}$, Candice K. Emmons ${ }^{1}$, Gregory S. Schorr ${ }^{2}$, \\ Brian Gisborne $^{3}$, Katherine L. Ayres ${ }^{5}$, Samuel K. Wasser ${ }^{5}$, Kenneth C. Balcomb ${ }^{6}$, Kelley \\ Balcomb-Bartok $^{6,8}$, John G. Sneva ${ }^{7}$, Michael J. Ford ${ }^{1}$ \\ ${ }^{1}$ National Marine Fisheries Service, Northwest Fisheries Science Center, Seattle, Washington 98112, USA \\ ${ }^{2}$ Cascadia Research Collective, Olympia, Washington 98501, USA \\ ${ }^{3}$ Fisheries and Oceans Canada, Pacific Biological Station, Nanaimo, British Columbia V9T 6N7, Canada \\ ${ }^{4}$ Northwest Fisheries Science Center, Manchester Research Station, Manchester, Washington 98353, USA \\ ${ }^{5}$ University of Washington, Center for Conservation Biology, Department of Biology, Seattle, Washington 98195, USA \\ ${ }^{6}$ Center for Whale Research, Friday Harbor, Washington 98250, USA \\ ${ }^{7}$ Washington Department of Fish and Wildlife, Olympia, Washington 98501, USA \\ ${ }^{8}$ Present address: Renton City Hall, Renton, Washington 98057, USA
}

\begin{abstract}
Recovery plans for endangered southern resident killer whales Orcinus orca have identified reduced prey availability as a risk to the population. In order to better assess this risk, we studied prey selection from 2004 to 2008 in 2 regions of the whales' summer range: San Juan Islands, Washington and the western Strait of Juan de Fuca, British Columbia. Following the whales in a small boat, we collected fish scales and tissue remains from predation events, and feces, using a fine mesh net. Visual fish scale analysis and molecular genetic methods were used to identify the species consumed. Chinook salmon, a relatively rare species, was by far the most frequent prey item, confirming previous studies. For Chinook salmon prey, we used genetic identification methods to estimate the spawning region of origin. Of the Chinook salmon sampled, 80 to $90 \%$ were inferred to have originated from the Fraser River, and only 6 to $14 \%$ were inferred to have originated from Puget Sound area rivers. Within the Fraser River, the Upper Fraser, Middle Fraser, South Thompson River and Lower Fraser stocks were inferred to currently be sequentially important sources of Chinook salmon prey through the summer. This information will be of significant value in guiding management actions to recover the southern resident killer whale population.
\end{abstract}

KEY WORDS: Resident killer whales · Prey selection · Chinook salmon · Genetic stock identification

\section{INTRODUCTION}

Marine mammals are important predators in marine ecosystems (e.g. Williams et al. 2004), and predation by marine mammals on fish stocks of commercial or conservation concern is of continuing interest to marine resource managers (NMFS 1997,
DFO 2003). Interactions between fish and marine mammals have led to conservation concerns for both taxa. For example, several studies have found pinnipeds to be significant sources of mortality for threatened fish stocks (e.g. Bundy 2001, Weise \& Harvey 2005), while others have found reductions in fish prey abundance to be a significant problem for 
threatened pinniped species (Trites \& Donnelly 2003, Guenette et al. 2006).

Low prey abundance has been suggested as a risk factor impacting a population of killer whales Orcinus orca that was listed as endangered under the Canadian Species at Risk Act (SARA) and the US Endangered Species Act (ESA). The southern resident population of killer whales inhabits coastal waters from central California to northern British Columbia, but during the summer months is often present in the inland marine waters of Washington and southern British Columbia (see Fig. 1). A 6 yr decline in population size from 97 to 79 animals starting in 1995 led to a threatened listing in Canada in 1999, an endangered listing in Canada in 2001 (Baird 2001) and a petition for ESA listing in the US in 2001. Following 2 status reviews (Krahn et al. 2002, 2004), the population was listed as endangered under the ESA in 2005. Numerous risk factors may impact this population, including chemical contamination, threats from potential oil spills, a small population size (Krahn et al. 2002) and auditory (Holt et al. 2009) or behavioral disturbance from boat traffic in their summer range (Lusseau et al. 2009, Noren et al. 2009, Williams et al. 2009). Both of the latter factors may result in reduced foraging opportunities or increased energetic expenditures. An additional potentially important factor limiting their recovery is the possibility that their survival and fecundity are limited by prey abundance (Baird 2001, Krahn et al. 2002, Ward et al. 2009, Ford et al. 2009). Both the Canadian and US recovery plans highlight the need to understand prey selection in order to fully assess the potential impacts of limitations in prey availability (DFO 2008, NMFS 2008b). The specific mechanisms of mortality associated with poor nutrition are not well understood, but could include indirect mechanisms such as greater mobilization of lipid stores and thus higher blood contaminant levels (Krahn et al. 2009) or outright starvation.

The plausibility that the southern resident killer whale population may be limited by prey abundance is increased by the dietary specializations of this species. By following and observing known distinctive individuals, Bigg (1982) discovered that killer whales in the Vancouver Island area were divided into sympatric populations with prey preferences for either marine mammals (so-called transients) or fish (so-called residents). These dietary specializations have been confirmed with over $30 \mathrm{yr}$ of direct observations (Ford et al. 1998, 2000), and are associated with a suite of life history differences between the fish-eating and mammal-eating population types (reviewed by Baird 2000, Ford et al. 2000). Dietary specialization among killer whale populations has been reported from a variety of areas worldwide (e.g. Matkin \& Dahlheim 1995, Matkin et al. 2007, Pitman et al. 2007).
There are several distinct populations of resident (fish-eating) killer whales in the eastern North Pacific (Barrett-Lennard 2000, Ford et al. 2000, Hoelzel et al. 2002, 2007). Previous studies of the diet of the southern residents and the closely related northern resident population have shown that Pacific salmon Oncorhynchus spp., in particular Chinook salmon O. tshawytscha, appear to be a preferred prey item during the summer and fall months when the whales are in the inland waters of northern Washington and southern British Columbia (Ford et al. 1998, Ford \& Ellis 2006). In particular, Ford et al. (1998) developed a method of monitoring the whales' behavior for foraging cues with subsequent recovery of fish scales that provides information on the species and age structure of the whales' prey. Ford \& Ellis (2006) expanded upon this work by employing focal-follow behavioral monitoring and genetic analysis to identify species from recovered fish tissues. Together, these studies provided significant support for a Chinook salmon preference by northern and southern resident populations, as well as information on the whales' behavior, including the occurrence of prey sharing (Ford \& Ellis 2006).

While these studies established the validity and value of the focal-follow approach for assessing prey preferences, the efforts were focused primarily on northern residents, and the number of samples collected from southern resident killer whales was relatively small (46 predation events; Ford \& Ellis 2006). Confirming the importance of Chinook salmon in the diet of southern resident killer whales is important for understanding factors potentially limiting population recovery. In addition, information on which stocks of Chinook salmon this population consumes is also of value: 9 Chinook salmon evolutionarily significant units (ESUs) within the range of southern resident killer whales are themselves listed as threatened or endangered under the ESA (NMFS 2005), even while in some cases they continue to be subjected to significant fisheries (PSC 2007). Most Chinook salmon ESUs are also at risk from a variety of additional factors, including habitat degradation, genetic and ecological impacts from hatchery production and impacts from hydropower (NMFS 2005). In addition, there are numerous Canadian populations of Chinook salmon (Candy et al. 2002, Holtby \& Ciruna 2007) which occur within the range of southern resident killer whales in Canada (Krahn et al. 2004), of which the statuses of some are of concern to managers (PSC 2008b). If Chinook salmon constitute the bulk of these whales' diet, then fish managers will need to take this information into account when managing Chinook salmon fisheries and conservation efforts (NMFS 2008a).

The present study was designed to increase the number of southern resident prey samples and to determine the region of origin of Chinook salmon prey 
taken by the whales in their summer range. We used both visual analysis of fish scales and molecular genetic techniques to identify prey species. For Chinook salmon we also used genetic stock identification methods to infer the prey samples' regions of origin.

\section{MATERIALS AND METHODS}

Field methods. Field activities were based out of the San Juan Islands (SJI), and Port Renfrew, British Columbia, in Juan de Fuca Strait (JDFS), and were undertaken during summer months from 2004 to 2008 using a $6 \mathrm{~m}$ rigid-hulled inflatable boat (WA) and in 2007 using a $12 \mathrm{~m}$ welded aluminum boat (BC). Prior to each day's field work, killer whales were located based on sightings reported by other researchers, commercial whale watching operators or The Whale Museum's Soundwatch Program. Similar to previous studies of killer whales (Baird \& Dill 1995, Ford \& Ellis 2006), for each encounter we recorded location, $\operatorname{pod}(\mathrm{s})$ present, the approximate area covered by the group of whales (an indicator of how spread out the group was) and the focal animal or group (sensu Altmann 1974).

Identities of individual whales in the focal group were recorded whenever possible. We used a published cata$\log$ (Center for Whale Research 2008) to identify individual whales. Although we identified which pods were present during an encounter, we were generally unable to determine whether all the members of a specific pod were present in any given encounter. To confirm the identity of difficult-to-identify individuals, we attempted to obtain photographs of the dorsal fin of whales in focal groups or from which prey remains were collected. Photographs were taken with digital SLR cameras with lenses ranging from 100 to $300 \mathrm{~mm}$ in focal length.

To minimize potential conflicts with shore- and boatbased whale watchers in US waters, we did not closely approach the whales if they were $<500 \mathrm{~m}$ from shore in areas of high human habitation, or if more than 2 whale-watching boats were near a tightly spaced $\left(0.25 \mathrm{~km}^{2}\right.$ or less) group of whales. We collected samples using 2 different approaches depending on the number of whales in the immediate vicinity. Following Ford \& Ellis (2006), whenever possible we closely followed one or more focal whales and attempted to obtain predation event samples associated with just those whales. Alternatively, if the number of whales near the boat was too great to keep track of individual whales, we collected samples opportunistically. We did not attempt to distribute effort randomly or evenly between different pods or individuals, but chose whales to follow based primarily on distance from commercial or recreational whale-watching vessels and areas of high human habitation.
The method we used for predation event detection was similar to Ford \& Ellis (2006) and the sample collection method was based on the approach developed by Ford et al. (1998). In the San Juan Island area, follows and approaches were typically undertaken in the late afternoon and evening hours due to the difficulty of finding the whales' location(s) in the early morning and the subsequent occurrence of a large number of boats near the whales in the morning through mid-day and afternoon. We used several cues (e.g. fast directional or non-directional, moderate non- directional, first surface after a long dive or whales converging) to trigger close approaches to look for fish parts. Whenever any whale surfaced less than $20 \mathrm{~m}$ from the boat, we would also watch the mouth-line of the whale to try to assess whether it was carrying prey. Upon observing 1 or more cues we would approach the fluke print (glassy areas of water caused by upwelling from the whales' tail as it dives) of the focal whale, noting the presence of other whales nearby and recording information on any interactions between the focal whale and other whales (e.g. change in distance among whales). Approaches were always made in a way to avoid or minimize disturbance to the whale(s) present, by slowing the vessel speed either to stop in the fluke print if the whale was still actively non-directionally surfacing or matching the speed and direction of the whale upon arrival at the fluke print.

Once at the fluke print, we recorded whether we observed any fish, fish scales, fish parts, fecal material or other type of material discharged by the whales. If material was observed, we recorded the estimated number of prey parts or other material visible in the water column. When no material was observed in the first fluke print, we would proceed to subsequent fluke prints. We also collected feces and regurgitations from or between fluke prints in the San Juan Islands. Feces were identified as semi-cohesive brownish to greenish material in the water column or floating at the surface. Regurgitations were identified as a cloud of very fine parts (including, in the case of juveniles, light-colored material, presumably milk) and were confirmed by the presence of items not recovered from predation events (i.e. bones and nematodes), while scales were absent and were typically from individuals not showing any other cues of foraging or prey chases. We used a longhandled $(4 \mathrm{~m})$ fine-mesh net to collect any material observed in the water. Samples collected in the US were stored in plastic bags in a cooler while in the field. Prey samples (comprised of 1 or more prey parts) were later stored at $-80^{\circ} \mathrm{C}$ prior to analyses, except for fish scales which were removed from the initial sample bag and dried at room temperature. Samples collected in $\mathrm{BC}$ were transferred directly into a vial of ethanol (Ford \& Ellis 2006). Each type of preservation method 
is used routinely by respective fisheries management agencies (i.e. Washington Department of Fish and Wildlife, Department of Fisheries and Oceans Canada), which both require preservation of scale structure for visual ID of species and age as well as maintaining the viability of the material for genetic analyses.

Genetic analyses. Genetic analyses were similar to those used by Ford \& Ellis (2006). Scales collected in the San Juan Islands were initially air-dried and visually (48x magnification) examined to determine species and age from marine and freshwater annuli patterns (Jearld 1983). We then extracted DNA from fish scales and other prey samples using standard methods. We also used fecal samples that yielded sufficient DNA to allow stock assignment. Salmonid prey remains were identified visually, and species was determined by PCR amplification and sequencing the COIII/ND3 region of the mitochondrial genome using the primers and PCR reaction conditions described in Purcell et al. (2004).

For the Chinook salmon prey samples collected in Washington waters, we used a coast-wide data set of genotypes at 13 microsatellite loci recently developed by a consortium of laboratories (Genetic Analyses of Pacific Salmonids [GAPS]; Seeb et al. 2007) to infer the region of origin of the Chinook salmon prey samples. Samples collected in BC waters were analyzed similarly using the coast-wide baseline described in Beacham et al. (2006).

The 2 baseline databases are similar, each consisting of genotypes from $>20000$ Chinook salmon sampled from $>150$ populations ranging from central California to Alaska. The known population samples were grouped into regional reporting groups based upon their genetic similarity to each other, and the proportional contributions of the reporting groups to overall prey sample were estimated using the method of Pella \& Masuda (2001) as implemented in the program cBayes (Neaves et al. 2005). The result is an estimate of the percentage (and standard error) of each reporting group within the prey samples. The statistical sig- nificance of differences between mixture samples from different times or places was evaluated directly from the allele frequencies in the prey samples using a contingency test of homogeneity between samples, as implemented in the program GENEPOP 4.0 (Raymond \& Rousset 1995a,b, Rousset 2008). This method uses a Markov Chain Monte Carlo randomization approach to directly estimate the probability of the null hypothesis that sample groups were drawn from the same allele frequency distribution at a locus. The $\mathrm{p}$-value for the null hypothesis considering all loci was then calculated using Fisher's method. Rejection of the null hypothesis indicates that the 2 samples were drawn from different mixtures of stocks, although it does not indicate which stocks contribute to the statistical rejection of homogeneity of allele frequencies.

\section{RESULTS}

From 2004 to 2008, southern resident killer whales were encountered in the San Juan Islands on $114 \mathrm{~d}$ of effort from May through September and in the western Juan de Fuca Strait on 35 d from June through early September 2007 (Table 1), during which 163 and 75 predation event collections were made in each area, respectively. In addition, in the SJI we collected 6 regurgitations and 101 fecal samples. Although sampling efforts in both areas were opportunistic, in SJI we encountered J pod nearly twice as often (47 encounters) as K (20) or L (26) pods when the pod could be identified or the whales were not in mixed pod aggregations. The encounters which occurred in the JDFS, (for which pods could be identified), were more often with L pod (9) than with K (3) or J (2) pods. Samples were collected from all 3 southern resident pods in both areas, although the majority of the samples (prey/fecal) in the SJI were from J pod (77/28) with fewer from L (29/19) and K (15/10) pods. Conversely, in the JDFS most prey samples were collected from L pod

Table 1. Summary of sampling effort and sample type recovered from southern resident killer whales during May to September 2004 to 2008 in the Juan de Fuca Strait (JDFS) and San Juan Island (SJI) study areas. No sampling was conducted in May in JDFS. $(-)$ : No attempt made to collect fecal samples in JDFS

\begin{tabular}{|c|c|c|c|c|c|c|c|}
\hline \multicolumn{2}{|c|}{ Sampling month } & \multicolumn{2}{|c|}{ Days of effort } & \multicolumn{2}{|c|}{ No. of scale/tissue samples } & \multicolumn{2}{|c|}{ No. of fecal samples } \\
\hline JDFS & SJI & JDFS & SJI & JDFS & SJI & JDFS & SJI \\
\hline & May 2006-2008 & & 11 & & $13^{\mathrm{a}}$ & & 2 \\
\hline Jun 2007 & Jun 2005-2008 & 5 & 30 & 19 & $53^{b}$ & - & 26 \\
\hline Jul 2007 & Jul 2005-2008 & 10 & 17 & 23 & 24 & - & 6 \\
\hline Aug 2007 & Aug 2004-2008 & 18 & 26 & 32 & 32 & - & 20 \\
\hline Sep 2007 & Sep 2005-2008 & 2 & 30 & 1 & $41^{\mathrm{c}}$ & - & 47 \\
\hline Total & & 35 & 114 & 75 & 163 & & 101 \\
\hline
\end{tabular}


(15), whereas for the remaining 12 samples where pod ID was noted, any of the members of all 3 pods could have been responsible. Only 15 samples were collected in May, all of which were from J pod.

Prey samples from the SJI were collected in US waters from Hein Bank in the central JDFS north to Point Roberts in the southern Strait of Georgia, but most were collected on the southwest side of San Juan Island (Fig. 1), where all 3 pods spend much of their time in summer months (Hauser 2006, Hauser et al. 2007). Samples collected in the western JDFS were all collected in Canadian waters, from Tsusiat Point in the west to Beechey Head in the east, with most samples collected between Carmanah Point and Sombrio River, an area that was frequented more often by L pod (Hauser et al. 2007), although all 3 pods were documented in that area.

\section{Species composition}

We collected 157 scale and tissue samples from predation events, 6 regurgitation samples and 101 fecal samples in the SJI area. A total of 158 of the tissue and scale samples, including all 6 regurgitation samples, and 69 of the fecal samples could be used for species identification (Table 2). Only 1 of the scale and tissue samples and 8 of the fecal samples were from species other than salmonids. Scale analysis species classification agreed with the genetic species classification for salmonids. Of the 75 scale and tissue samples collected in the JDFS area, all were from salmonids. Chinook salmon was the most prevalent salmonid species in all sample types, and in each month in both sample areas. Of the non-salmonids, all of which were collected in the SJI area, the prey item was an unidentified flatfish, and the fecal samples included lingcod Ophiodon elongatus, halibut Hippoglossus stenolepis, rockfish Sebastes spp. and Dover sole Microstomus pacificus. The proportion of Chinook salmon in the samples was highest in midsummer $(>90 \%)$ and lower in May $(50 \%)$ in the SJI (no collections were made in JDFS in May and only 1 in September). Steelhead Oncorhynchus mykiss was nearly as common as Chinook salmon in May in the SJI, although the sample size was small. Three steelhead were also recovered in June and in September. One sockeye salmon Oncorhynchus nerka was taken in July and 3 in August. Two chum salmon Oncorhynchus keta were recovered in June and 1 in July. In the SJI, 1 coho salmon Oncorhynchus kisutch was recovered in June, 2 were recovered in August and 4 were recovered in September. Only 1 coho salmon was recovered in the JDFS (in September).

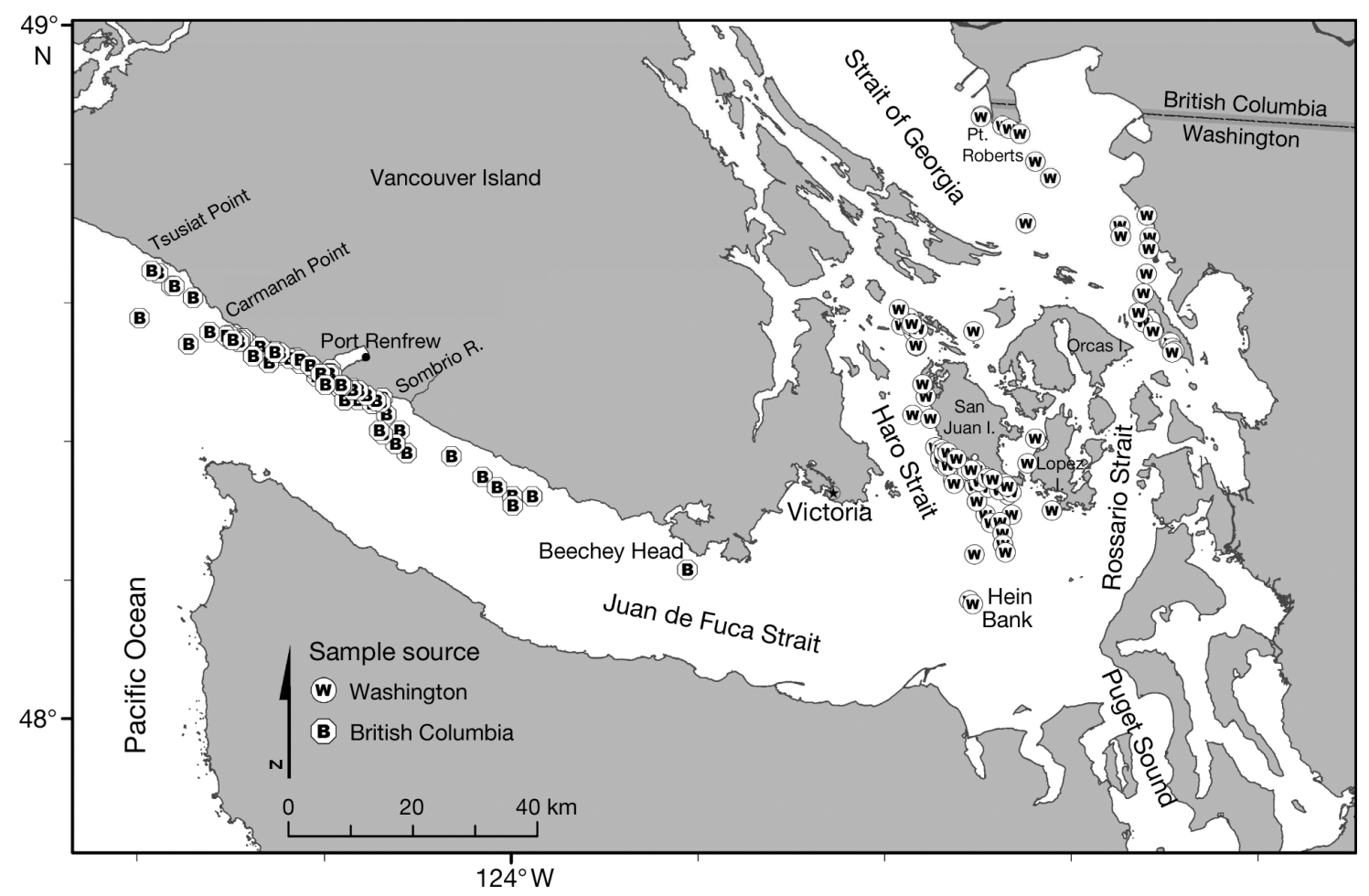

Fig. 1. Western Juan de Fuca Strait and San Juan Island study areas for collection of prey samples by southern resident killer whales from May to September 2004 to 2008. Each point represents the location of an individual prey sample included in the analysis 
Table 2. Total number of southern resident killer prey species identified from scale (S) or tissue (T), including regurgitations and fecal (F) analysis in the Juan de Fuca Strait (JDFS) and San Juan Islands (SJI). SJI samples do not include all 2008 fecal samples. Blanks indicate that no samples were collected

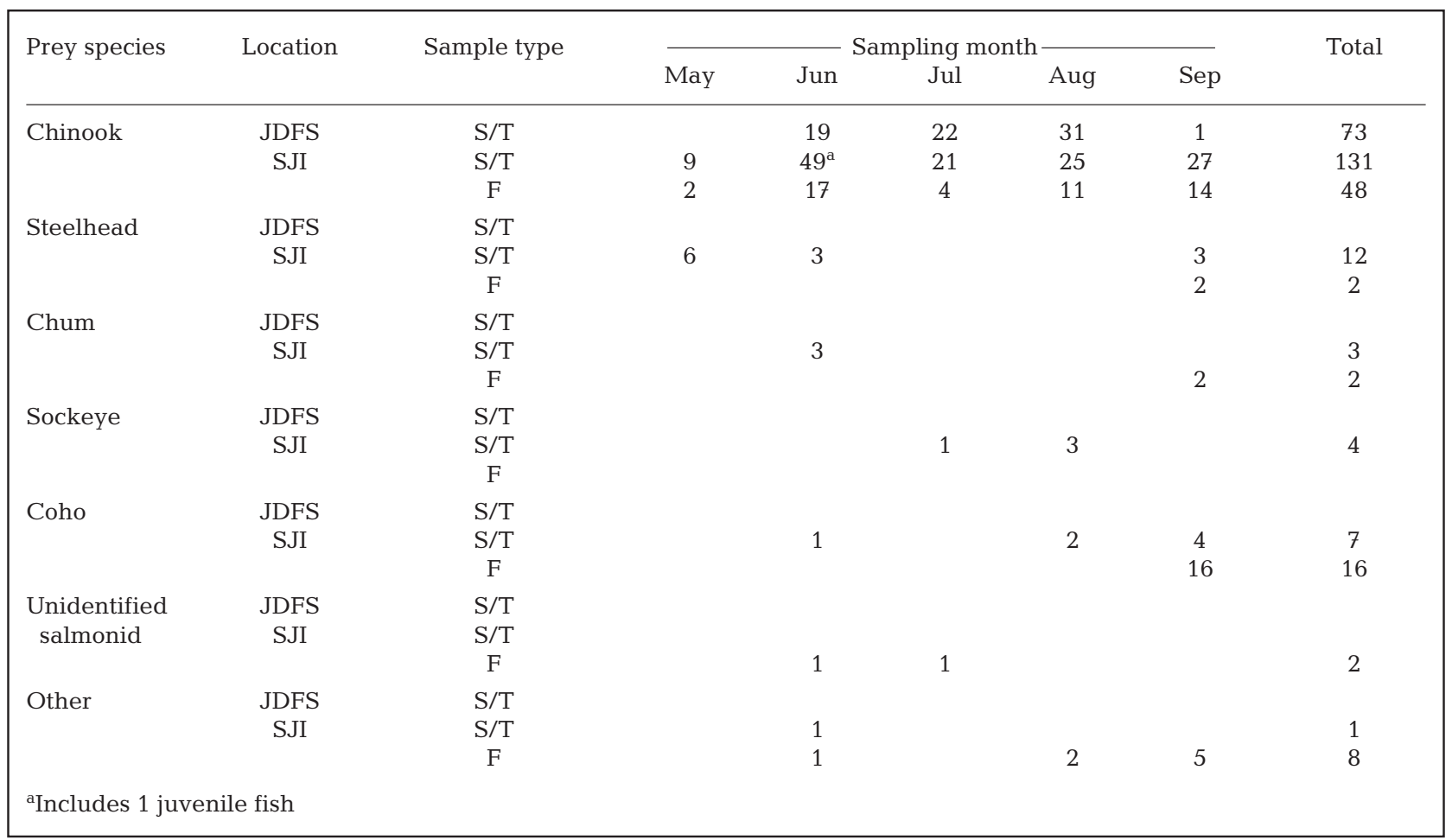

\section{Stock composition of Chinook samples}

Of the 179 samples that contained Chinook salmon DNA in the SJI (131 from scales or tissues and regurgitations and 48 fecals), we were able to obtain genotypes from 105 of them (98 tissue and scales and 7 fecals) for at least 5 loci. For the JDFS, of the 74 samples with Chinook salmon DNA, 73 produced useful genotypes for mixture analysis. The majority of Chinook salmon from both study areas was estimated to be predominately of Fraser River origin, although the SJI had a higher proportion (89.7\%) than the JDFS (79.7\%) (Table 3, Fig. 2). For the months in common (June, July, August), the allele frequencies in the prey samples from the 2 sampling areas differed significantly overall $\left(\chi^{2}=26.3 \mathrm{df}=\right.$ $8, p=0.00092)$. None of the comparisons within months between areas were significant $\left(\chi^{2}=12.2, \mathrm{df}=8, \mathrm{p}=\right.$ $0.14 ; \chi^{2}=11.5, \mathrm{df}=8, \mathrm{p}=0.17 ; \chi^{2}=9.5, \mathrm{df}=8, \mathrm{p}=0.30$ for June, July and August, respectively), perhaps due to small sample sizes. Allele frequencies differed significantly among months within both the SJI $\left(\chi^{2}=\infty\right.$, df $=$ $26, \mathrm{p}<0.00001)$ and JDFS $\left(\chi^{2}=58.8, \mathrm{df}=24, \mathrm{p}=.00009\right)$ sampling areas, and most of the pair-wise comparisons among months within sampling areas were also highly significant (Table 3).

The composition of the Chinook salmon stocks varied seasonally, and for the Fraser River stocks this vari- ation reflected the expected seasonal composition of Chinook salmon from that river system. In particular, in May and June, the Fraser River stocks in the prey samples were dominated by stocks from the upper portion of the watershed (Fig. 2). In July and August, stocks from the central portion of the watershed were most common, while in September the predominant Fraser River stocks were from the lower watershed, a pattern consistent with the seasonal distribution of the major Fraser River Chinook salmon stocks as they enter the river mouth (Parken et al. 2008).

The contribution of non-Fraser River stocks also varied seasonally and between the 2 prey sampling areas. In May in the SJI, Fraser River stocks were estimated to make up only about one-third of the prey composition, with stocks from South Puget Sound, Hood Canal and California forming the majority of the sample (Table 3). However, the sample size for May was relatively small ( $\mathrm{n}=9$ ), so these estimates have large standard errors (Table 3). By June, Fraser River stocks made up the majority of the samples in both study areas, although the Middle Fraser and North Thompson (a tributary of the Fraser) were much lower in the SJI. Similarly, North Puget Sound stocks were estimated to be $\sim 10 \%$ of the sample in the JDFS but were not seen in the SJI. In July, Fraser River stocks continued to dominate both areas, but a reversal was seen in 
Table 3. Estimated mean percentage $( \pm \mathrm{SE}$ ) of Chinook salmon stock composition of killer whale prey from the Juan de Fuca Strait (JDFS) and the San Juan Islands (SJI) based on predation event remains and fecal samples

\begin{tabular}{|c|c|c|c|c|c|c|c|c|c|c|}
\hline \multirow[b]{2}{*}{ Chinook stock } & \multicolumn{2}{|c|}{ Overall estimates ${ }^{a}$} & \multirow[b]{2}{*}{$\begin{array}{c}\text { May } \\
\text { SJI } \\
(\mathrm{n}=9)\end{array}$} & & & & & \multirow[b]{2}{*}{$\begin{array}{c}\text { Septembe } \\
\text { SJI } \\
(\mathrm{n}=17)\end{array}$} \\
\hline & $\begin{array}{l}\text { JDFS } \\
(\mathrm{n}=73\end{array}$ & $\begin{array}{c}\text { SJI } \\
(\mathrm{n}=105)\end{array}$ & & $\begin{array}{l}\underbrace{}_{(\mathrm{JDFS}} \text { Jun } \\
(\mathrm{n}=19)\end{array}$ & $\begin{array}{c}\text { SJI } \\
(\mathrm{n}=41)\end{array}$ & $\begin{array}{c}\overline{\text { JDFS }} \\
(\mathrm{n}=22)\end{array}$ & $\begin{array}{c}\text { SJI } \\
(\mathrm{n}=15)\end{array}$ & $\begin{array}{c}\text { JDFS } \\
(\mathrm{n}=32)\end{array}$ & $\begin{array}{l}\text { gust } \\
\qquad \begin{array}{l}\text { SJI } \\
(\mathrm{n}=23)\end{array}\end{array}$ & \\
\hline \multicolumn{11}{|l|}{ Region } \\
\hline Central BC Coast & $0.8 \pm 1.1$ & $0.1 \pm 0.4$ & $0.2 \pm 1.1$ & $0.0 \pm 1.2$ & $0.3 \pm 1.1$ & $0.0 \pm 1.1$ & $0.1 \pm 0.8$ & $0.0 \pm 0.9$ & $0.2 \pm 1.1$ & $0.2 \pm 1.0$ \\
\hline W Vancouver I. & $8.6 \pm 2.9$ & $0.1 \pm 0.2$ & $0.4 \pm 2.0$ & $0.0 \pm 1.2$ & $0.1 \pm 0.5$ & $4.5 \pm 4.0$ & $0.3 \pm 1.3$ & $6.3 \pm 4.5$ & $0.2 \pm 0.8$ & $0.3 \pm 1.3$ \\
\hline E Vancouver I. & $1.1 \pm 1.3$ & $0.0 \pm 0.2$ & $0.3 \pm 1.5$ & $2.5 \pm 4.3$ & $0.1 \pm 0.5$ & $0.3 \pm 2.0$ & $0.2 \pm 1.0$ & $0.0 \pm 0.9$ & $0.2 \pm 1.2$ & $0.2 \pm 1.0$ \\
\hline Fraser River (all) & 79.7 & 89.7 & 31.2 & 84.2 & 93.3 & 83.1 & 94.2 & 74.8 & 89.4 & 77.0 \\
\hline Upper Fraser & $11.7 \pm 3.7$ & $31.2 \pm 5.2$ & $18.6 \pm 15.0$ & $37.5 \pm 12.7$ & $77.3 \pm 6.6$ & $28.1 \pm 10.1$ & $6.6 \pm 8.1$ & $0.0 \pm 0.8$ & $0.2 \pm 1.1$ & $0.1 \pm 0.9$ \\
\hline Mid Fraser & $10.2 \pm 3.6$ & $19.1 \pm 4.7$ & $11.3 \pm 13.1$ & $17.9 \pm 9.9$ & $6.1 \pm 3.9$ & $34.4 \pm 10.6$ & $58.8 \pm 13.2$ & $0.0 \pm 0.9$ & $19.3 \pm 8.6$ & $0.2 \pm 1.3$ \\
\hline Lower Fraser & $10.1 \pm 4.2$ & $12.6 \pm 3.6$ & $0.5 \pm 2.6$ & $0.0 \pm 1.4$ & $0.1 \pm 0.3$ & $0.0 \pm 1.3$ & $0.1 \pm 0.8$ & $15.7 \pm 6.9$ & $15.7 \pm 9.0$ & $54.2 \pm 12.4$ \\
\hline N Thompson & $5.5 \pm 2.8$ & $7.5 \pm 3.0$ & $0.3 \pm 1.9$ & $22.4 \pm 10.2$ & $0.1 \pm 0.5$ & $0.1 \pm 1.1$ & $15.8 \pm 9.6$ & $0.0 \pm 0.5$ & $4.5 \pm 4.7$ & $0.8 \pm 3.5$ \\
\hline S Thompson & $35.3 \pm 5.0$ & $16.9 \pm 4.0$ & $0.2 \pm 1.5$ & $2.9 \pm 4.5$ & $4.8 \pm 3.2$ & $20.6 \pm 9.0$ & $12.7 \pm 8.1$ & $59.0 \pm 8.7$ & $49.5 \pm 11.5$ & $17.7 \pm 10.4$ \\
\hline Lower Thompson & $0.8 \pm 1.4$ & $2.4 \pm 2.0$ & $0.2 \pm 1.6$ & $3.5 \pm 6.0$ & $5.0 \pm 3.4$ & $0.0 \pm 0.7$ & $0.1 \pm 1.0$ & $0.0 \pm 0.5$ & $0.1 \pm 0.7$ & $3.9 \pm 6.8$ \\
\hline N Puget Sound & $1.1 \pm 1.6$ & $2.4 \pm 2.3$ & $1.1 \pm 3.3$ & $10.6 \pm 12.2$ & $1.0 \pm 1.9$ & $9.0 \pm 7.8$ & $0.6 \pm 1.8$ & $0.4 \pm 2.0$ & $4.1 \pm 5.1$ & $17.8 \pm 10.1$ \\
\hline S Puget Sound & $13.0 \pm 5.7$ & $3.7 \pm 2.2$ & $25.3 \pm 20.7$ & $2.5 \pm 6.5$ & $1.7 \pm 2.3$ & $3.0 \pm 6.7$ & $0.2 \pm 1.2$ & $17.7 \pm 7.3$ & $0.3 \pm 1.3$ & $0.2 \pm 1.1$ \\
\hline Cent. Valley Fall & $0.0 \pm 0.2$ & $1.9 \pm 1.5$ & $21.2 \pm 12.9$ & $0.0 \pm 0.8$ & $0.1 \pm 0.3$ & $0.0 \pm 0.7$ & $0.2 \pm 1.1$ & $0.0 \pm 0.7$ & $0.1 \pm 0.8$ & $0.1 \pm 0.7$ \\
\hline Other & 1.9 & 2.2 & $20.4^{\mathrm{b}}$ & 0.2 & 3.5 & 0.1 & 4.2 & 0.7 & 5.4 & 4.3 \\
\hline \multicolumn{11}{|c|}{ 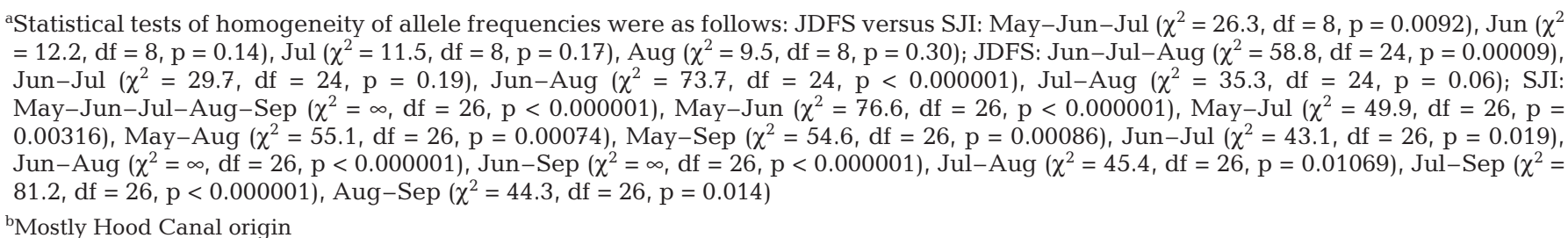 } \\
\hline
\end{tabular}
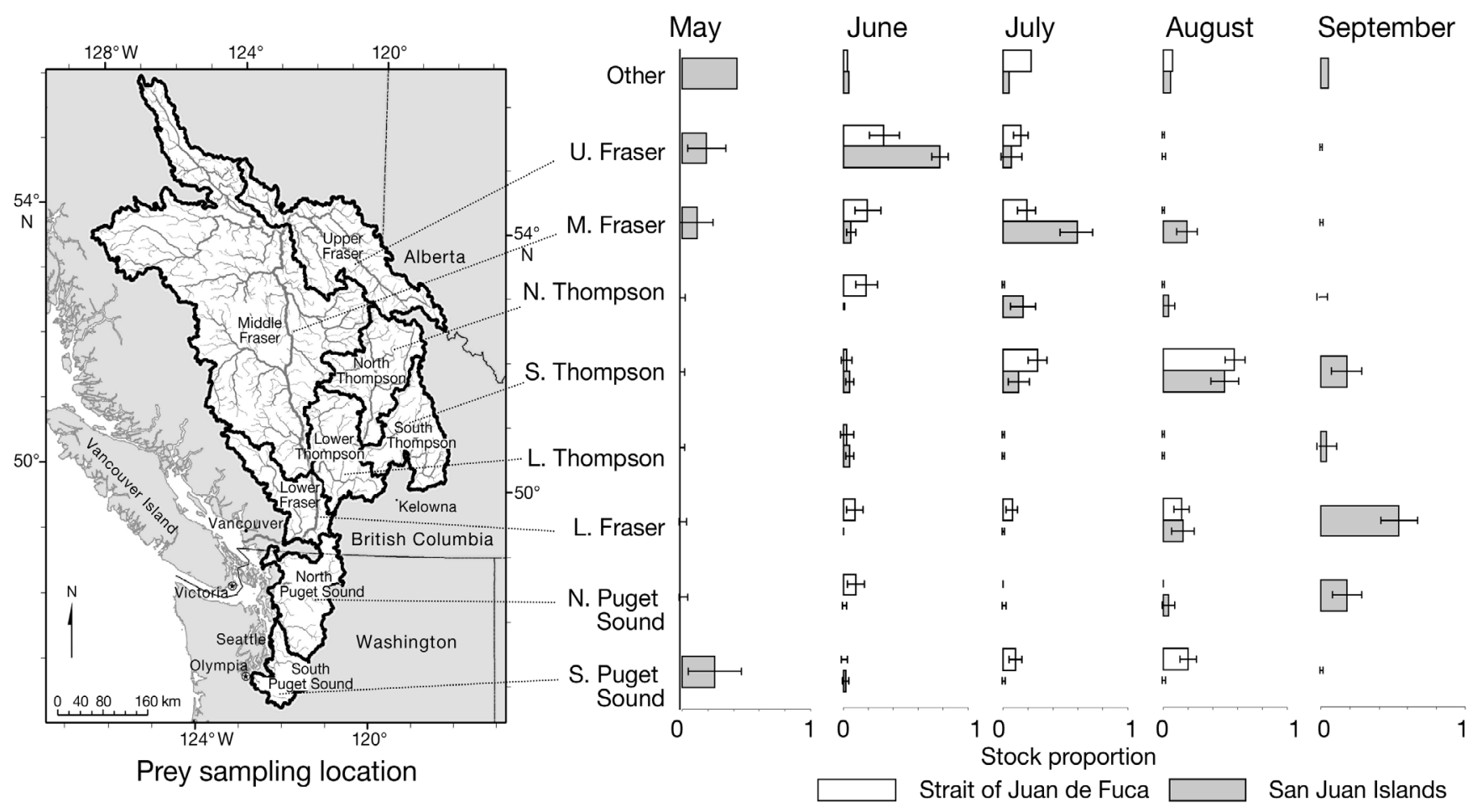

Fig. 2. Stock proportion $( \pm \mathrm{SE})$ of southern resident killer whale Chinook salmon prey items by study area and collection month 
presence of North Thompson stocks, and while Upper Fraser had declined slightly in the JDFS, they had decreased substantially in the SJI (Table 3). During this month, west coast Vancouver Island and Northern Puget Sound stocks were estimated to be at relatively high frequencies in the JDFS ( 4 and $\sim 9 \%$, respectively), but $<1 \%$ in the SJI. Similarly, in August the JDFS had a substantial proportion of South Puget Sound stocks $(\sim 18 \%)$ compared to $<1 \%$ South Puget Sound stocks in the SJI sample. The composition of Fraser River stocks differed substantially between the sampling areas during this month as well, with Middle Fraser River stocks estimated to make up $\sim 19 \%$ of the SJI sample but $0 \%$ of the JDFS sample (Table 3). Finally, September was the only sampling month with substantial estimates of North Puget Sound stocks $(\sim 18 \%)$ in the SJI sample.

\section{DISCUSSION}

\section{Species selection}

Our results confirm earlier studies suggesting that Chinook salmon are the dominant component of the southern resident killer whales' summer diet (Ford et al. 1998, Ford \& Ellis 2006). The more contemporary and larger sample size obtained in the present study adds considerable weight to previous reports that Chinook salmon are by far the preferred prey of the southern resident killer whales during the summer months. In fact, we observed a similar or even higher proportion of Chinook as prey during June-August than did Ford \& Ellis (2006) (83\% SJI, 99\% JDFS, versus $84 \%$ for SE Vancouver Island as derived from Table 6 in Ford \& Ellis [2006]). We also documented that the southern residents consumed some steelhead, especially in the spring and fall months, consistent with previous results from Ford \& Ellis (2006) and Felleman et al. (1991). Steelhead might be a significant prey item during the spring in the SJI when Chinook salmon are only just beginning to arrive. The presence of steelhead in our SJI samples is also consistent with observations of steelhead predation in central Puget Sound during the winter and spring by a lone northern resident killer whale, A73 (M. B. Hanson unpubl. data). The importance of steelhead in the diet of southern resident killer whales in spring is unclear, however, and additional effort is needed to fully assess its role considering the relatively low abundance of this species (R. Bison pers. comm.). It appears that May in the SJI might be a transitional month during which the whales need to forage on a wider variety of species and runs. September prey selection in the SJI also seems to follow a similar pat- tern as May, as the contribution of Chinook salmon declines and other salmonids become more prevalent. However, it is also important to note that for both of these months some or all of the southern resident pods may spend significant time outside the inland waters and as such may be foraging on different prey than reported here.

Notably absent from the samples were pink salmon, and there were only a few sockeye salmon, confirming Ford \& Ellis' (2006) previous observation that pink and sockeye salmon are not significant sources of prey for the whales, despite the high abundance of these species in the area. The limited number of sockeye salmon found in prey samples is particularly striking because the annual abundance of Fraser River sockeye runs is up to 100-fold greater than Fraser River Chinook salmon. For example, the estimated terminal run size of Chinook salmon to the mouth of the Fraser River from 2004 to 2006 ranged from 265274 to 333330 (PSC 2007). In contrast, typical run sizes of Fraser River sockeye range from $\sim 5$ to 20 million (PSC 2008a). It is not clear why the whales do not eat many sockeye since they do eat other salmonids, particularly early and late in the season. One possibility is that the peak of the sockeye salmon run in the area largely overlaps with the peak of the Chinook salmon run (Roos 1991, Parken et al. 2008), so the whales may not need to switch from their preferred prey during this time period (Ford \& Ellis 2006). The sockeye salmon runs are also of shorter duration than the Chinook salmon runs (Roos 1991, Parken et al. 2008), and perhaps the whales prefer a prey source that is available over a longer period of time (Ford \& Ellis 2006). Pink salmon return to the Fraser River in similar numbers as sockeye salmon, but only in odd years and with a return timing concentrated in late summer when Chinook salmon are also relatively abundant (Roos 1991).

\section{Chinook salmon stock assignments}

The predominance of salmon originating from the Fraser River in the diet of southern resident killer whales in both study areas was not unexpected because the whales' core summer habitat (Osborne 1999, McCluskey 2006, Hauser et al. 2007) coincides with the migration route of Fraser River salmon runs (Healey \& Groot 1987) and the co-occurrence of killer whales and salmon has been previously noted (Heimlich-Boran 1986, 1988, Felleman et al. 1991, Hoelzel 1993). The Fraser River Chinook salmon stocks are also the most abundant Chinook salmon populations that migrate through the area (PSC 2007). However, in May, Fraser River Chinook salmon are relatively rare (English et al. 2007, Parken et al. 2008) and, consistent 
with this rarity, Fraser River stocks were estimated to make up a lower fraction of the prey samples in May than in the other months (Table 2). The start of the significant return of Fraser River Chinook salmon to inland marine waters in June may be why $\mathrm{K}$ and $\mathrm{L}$ pods typically do not arrive back in the SJI from the coastal areas until this time (Osborne 1999). However, only 15 samples were collected in May, so conclusions regarding the prey composition early in the season will remain tentative until additional data are collected.

Although the stock composition estimates from the 2 sampling areas were both dominated by Fraser River stocks, there were significant differences in the overall stock composition estimates between the 2 areas. These differences are likely due to the location of the 2 areas relative to the migratory routes and timing of Chinook salmon runs in the region, since many salmon returning to the Fraser River have to migrate through the JDFS before they enter the SJI area (Fig. 1). Chinook salmon in the Fraser River are characterized by a distribution of seasonal times of return to freshwater (runs), with distinct spring, summer and fall run stocks. The stocks returning to spawn in the Upper Fraser are mostly spring-run, and at the Fraser River mouth their abundance peaks in late June and early July (Parken et al. 2008). Stocks from the Middle Fraser and North Thompson River tend to have a peak migration time of late July or early August, and stocks from the South Thompson River and Lower Fraser areas have peak migration times of late August and late September, respectively.

The differences in stock composition between the 2 sampling areas are consistent with the stock-specific run timing differences seen at the Fraser River mouth (Parken et al. 2008). In particular, the June JDFS samples have lower proportions of spring-run stocks (Upper Fraser) and higher proportions of summer run stocks (North Thompson and Middle Fraser) compared to the SJI samples (Fig. 2). A reasonable interpretation of this pattern is that most of the Upper Fraser (springrun) stocks had already moved through the JDFS prior to June, but were still the dominant stocks in the SJI. During the same time period, the Middle Fraser and North Thompson stocks were starting to appear in the JDFS but had not yet reached the SJI. By July, in contrast, North Thompson and Middle Fraser stocks were at higher frequencies in the SJI than in the JDFS, and by August these stocks were not seen in the JDFS at all and were much less frequent in the SJI (Fig. 2). The decline of South Thompson and increase of Lower Fraser fish in the SJI appears to be a continuation of this pattern.

The close correspondence of the stocks from prey samples from the SJI and the Fraser River run timing pattern noted above suggest that the whales are con- suming Chinook salmon stocks at least roughly in proportion to their abundance. The ratio between Fraser River and Puget Sound stocks in the prey samples also appears consistent with the relative abundance of these stocks. Based on terminal run abundance estimates of the major Fraser River and Puget Sound Chinook salmon stocks, Puget Sound stocks are estimated to make up $\sim 17 \%$ of the Chinook salmon returning to inland marine areas (PSC 2007, their Appendix B), a level that was similar to what we observed in the August and September prey samples.

The monthly stock composition of the prey samples was also generally reflective of the stock composition observed in various fisheries. In May, although the sample size was small, the Chinook salmon present were primarily from Puget Sound, similar to Chinook salmon caught in the recreational fishery in the Victoria fishery area that month (Bailey et al. 2001). Stock composition estimates of Chinook salmon taken as bycatch in tribal and commercial sockeye and pink salmon purse-seine fisheries in the SJI area during late August and early September 1998, 2006 and 2007 were dominated by South Thompson (62 to $67 \%$ ) and Lower Fraser (1 to $20 \%$ ) stocks (Blankenship et al. 2009). Stocks from those areas also made up high proportions of the August and September prey samples (Table 3), suggesting that the composition of Chinook salmon stocks captured by fisheries was similar to that of whale prey, when the collections analyzed overlapped geographically. However, the stock composition estimates from the prey samples were not similar to all fisheries samples. Although prey samples from the mid-Fraser River comprised the second most abundant stock in SJI in August (19.1\%), these were virtually absent in the purse-seine (0 to $6 \%$ ) and recreational fisheries $(0 \%)$. Specifically, in the Washington Department of Fish and Wildlife Area 7 recreational fishery management unit (SJI north to the Canadian border), the stock composition was substantially different in that it was dominated by south Puget Sound Chinook salmon, a stock that was essentially absent from the SJI prey samples $(0.2$ to $0.3 \%$, but represented $\sim 18 \%$ in the JDFS).

The discrepancy between the fishery data and whale samples within the SJI was likely due to most of the fishing effort being concentrated in central and southern Rosario Strait area from July through September (Blankenship et al. 2009), an area that the whales infrequently use during those months (Hauser et al. 2007) and where we did not collect any samples (Fig. 2). In areas where this fishery overlapped with prey samples collected (southwest side of San Juan Island), fish taken in the recreational fishery, like the prey samples, were primarily from the Fraser River. Similarly for the purse-seine fisheries, these samples 
were obtained in the Strait of Georgia, an area that overlaps with only some of prey samples collected. The differences between the prey and fishery stock compositions could be due to the relatively small sample sizes of both types of samples, combined with a patchy distribution of stocks in time and space. The whales and the fisheries may also be selective in the stocks taken, which could lead to different stock composition estimates. Differences exist in mean body size among returning Chinook salmon stocks (Healey 1991). Ford \& Ellis (2006) observed that the Chinook salmon recovered from northern resident killer whale predation events were older (and therefore larger) than what would been expected based on the estimated relative abundance of available age classes of Chinook salmon in the waters of NE Vancouver Island. It is also possible that fisheries may be selective. The Chinook salmon bycatch noted above was from purse-seine fisheries targeting sockeye and pink salmon relatively close to the surface, whereas the recreational fisheries likely catch fish across a wide variety of depths. Dive profiles from time depth-recorders attached to southern resident killer whales show that dives in excess of $100 \mathrm{~m}$ are not unusual (Baird et al. 2005) and collection of prey samples often occur after long (i.e. deep) dives (Northwest Fisheries Science Center unpubl. data).

Despite some differences between the stock composition of the prey samples and those from nearby fisheries, the general pattern that the composition of the prey samples appears to roughly reflect the composition of the Chinook salmon stocks in the area has some important implications. In particular, although the results from the present and previous studies (Ford et al. 1998, 2000, Ford \& Ellis 2006) have provided a good picture of the whales' diet while they are in inland marine waters, much less information exists about the whales' diet during the large proportion of the time they are in the outer coastal areas. Assuming their diet on the outer coast is also mostly Chinook salmon (Black et al. 2001, Zamon et al. 2007), our results suggest that it is also reasonable to assume that the whales are preying on Chinook salmon stocks roughly in proportion to the stocks' abundance. However, considering the differences between the Chinook salmon fishery composition and the composition of the prey samples from a similar time and area discussed above, it is clear that there can also be some differences between the whales' prey composition and those of nearby fisheries.

In addition to differences due to run timing, some of the differences in stock composition between the SJI and JDFS prey samples likely reflect differences in the marine distributions of salmon stocks. For example, the higher proportion of South Puget Sound stocks in JDFS prey samples is consistent with previous studies that indicate that Chinook salmon from South Puget Sound return along the west coast of Vancouver Island (PSC 2007) and then move to the southern side of the JDFS before entering Puget Sound (Marshall et al. 1991). The lack of West Coast Vancouver Island Chinook salmon in the SJI sample is not surprising because these fish would not return through that area to their natal rivers. However, it was surprising that although North Puget Sound fish were only present in the JDFS sample in June, it was not until September that they made a substantial contribution in the SJI, suggesting that perhaps these stocks spend a considerable time holding in the JDFS before returning to spawn.

The results of the present study have important implications for salmon management actions aimed at the conservation of killer whales. Southern resident killer whale survival and fecundity are correlated with Chinook salmon abundance (Ward et al. 2009, Ford et al. 2009). Many salmon populations are themselves at risk, with 9 ESUs of Chinook salmon listed as threatened or endangered under the ESA. Among the stocks we found to be consumed by the whales, the North and South Puget Sound stocks are part of the Puget Sound Chinook salmon ESU that is listed as threatened (NMFS 2005). In addition, the North Puget Sound spring and fall Chinook salmon stocks and several Fraser River spring and summer stocks (Bailey et al. 2001, Parken et al. 2008) have been listed as having medium to high conservation concern and fishery relevance (PSC 2008b). The endangered status of the southern resident killer whales and their apparent dependence on salmon as a prey source means that the National Marine Fisheries Service has been required to evaluate the effects of prey reduction on the whales due to fisheries (NMFS 2008a) and other activities (e.g. water diversions; NMFS 2009). The results from the present study will allow fish managers to potentially fine tune their activities to meet both salmon and whale recovery goals. For example, our results suggest that the whales may be particularly dependent upon Fraser River Chinook salmon stocks during the summer months. In considering the risk of fisheries to the whales via prey reduction, it may therefore make sense to pay particular attention to fisheries that impact these stocks.

In addition to considering the effects of reduced abundance of wild salmon on the whales, our results may also inform an assessment of the potential importance of hatchery-produced salmon in meeting the whale's prey requirements. The data we collected did not allow us to specifically identify hatchery fish in the samples we obtained. However, it is highly likely that some of fish consumed by whales included hatchery fish, because some of the stocks we identified in the whales' diet contain high proportions of hatchery ori- 
gin fish. For example, in many of the South Puget Sound Chinook salmon stocks, the hatchery contribution to these runs exceeds 75\% (Pacific Fishery Management Council 2009), and hatchery fish account for approximately $30 \%$ of the run of Lower Fraser River Chinook salmon (C. Parken pers. comm.). In the long term, hatchery production has been identified as an important risk factor impacting the viability of wild salmon stocks (Myers et al. 1998), and reducing hatchery releases has been used as a conservation strategy for wild salmon (Mobrand et al. 2005, Buhle et al. 2009). In the short term, however, our results suggest that managers may need to consider the potential impacts of reduced killer whale prey that may result by reducing releases of hatchery salmon.

The present study has provided important new information on the species and stocks of prey taken by southern resident killer whales in summer months. In particular, the present study has added to the evidence that the whales consume mostly Chinook salmon during this time period, and has provided a fairly detailed picture of how the stock composition of Chinook salmon they consume changes over the course of this season. However, it is important to note that the present study has some limitations. First, it relies primarily on the collection of prey fragments that are only recovered at or near the surface. There has been some concern that prey remains collected on the surface could be a biased sample if the whales are catching and consuming other types of prey while at depth (Ford et al. 1998, Baird et al. 2005). Recently, Ford \& Ellis (2006) observed that the whales tend to routinely bring prey that are caught at depth to the surface for prey sharing, suggesting that surface-collected prey is probably a reasonably unbiased sample of the total prey taken. However, the whales sometimes dive to considerable depths (Baird et al. 2005) and it remains possible that some types of prey items may be consumed far below the surface. Our results (Table 2) did show some differences in species contributions from scales and tissues versus feces (e.g. a higher proportion of coho and nonsalmonids in feces), such that analyses of additional fecal samples collected from the whales may help to address this issue. Secondly, the present study was limited to inland marine waters during the summer months, and the results may not be representative of the whales' diet in other areas or times of the year. During the fall, winter and spring months, the whales spend most of their time in outer coastal waters, ranging from central California to northern BC (Krahn et al. 2004) where they would have access to numerous other stocks of Chinook salmon (Weitkamp 2010) as well as other potential prey sources. Even during the summer months, the whales sometimes make multiday sojourns to the outer coastal waters, so the esti- mated prey composition we reported in the present study does not necessarily reflect their overall summer diet. It will therefore be important to conduct similar studies in outer coastal areas in order to gain a more complete understanding of the whales' diet composition. The present study provides an important foundation upon which to assess impacts of identified risk factors (Krahn et al. 2004). Specifically, next steps will include assessing the impact of southern resident killer whales on Fraser River salmon stocks as well as providing more realistic estimates of the intake of persistent organic pollutants than those of a recent analysis (Cullon et al. 2009).

Acknowledgements. We are particularly appreciative of $\mathrm{M}$. Ferguson's assistance in the first few field events and for helping define the data recording protocol. The following assisted in sample collections and behavioral observations: N. Barker, S. Courbis, E. Falcone, A. Foote, M. Fraker, J. Gaydos, D. Giles, A. Gill, A. Gorgone, D. Grebner, B. Hopper, J. Huggins, J. Jacobsen, M. Jasny, L. Jones, K. Koski, A. Larson, D. Larson, J. Lucas, S. Mahaffy, J. Palmer, M. Paquin, F. Roberston, J. Smith, V. Viers, L. Walker, A. Ü and A. van Ginneken. B. Onorato, S. Aggerguard, R. Bates, D. Noren and J. Marsh and the Port Renfrew sport fishing charter operators assisted in finding whales. We thank D. Ellifrit of the Center for Whale Research for confirming whale identifications from photographs. R. Bailey and C. Parken of Fisheries and Oceans Canada (DFO) provided information on Fraser River Chinook salmon runs. Stock composition analyses were made possible in part by the 11 laboratories that contributed to the GAPS database. S. Blankenship, Washington Department of Fish and Wildlife, provided data and assistance related to fisheries stock ID in Washington. D. Holzer and K. Neely prepared the figures. The University of Washington Friday Harbor Labs, R. and M. Strathmann and S. Hallquist provided housing and moorage. Research was undertaken under the authority of NMFS General Authorization No. 781-1725 and NMFS Scientific Research Permits 781-1824-01 and 532-1822 in US waters, and DFO 2006-27/SARA-54 in Canadian waters. We thank R. Currey and 2 anonymous reviewers for their helpful comments on the manuscript.

\section{LITERATURE CITED}

Altmann J (1974) Observational study of behavior: sampling methods. Behaviour 49:227-267

Bailey RE, Irvine JR, Candy JR, Parken CK, Lemke SL, Sullivan M, Wetklo M (2001) Summary of stock assessment information for selected early returning Chinook salmon populations of the Fraser River watershed. Research Document 2001/134, Canadian Science Advisory Secretariat, Ottawa, ON, available at www.dfo-mpo.gc.ca/csas/

Baird RW (2000) The killer whale: foraging specializations and group hunting. In: Mann J, Connor RC, Tyack PL, Whitehead $\mathrm{H}$ (eds) Cetacean societies: field studies of dolphins and whales. University of Chicago, London, p 127-153

Baird RW (2001) Status of killer whales, Orcinus orca, in Canada. Can Field Nat 15:676-701

> Baird RW, Dill LM (1995) Occurrence and behavior of transient killer whales: seasonal and pod-specific variability, 
foraging behavior, and prey handling. Can J Zool 73: 1300-1311

Baird RW, Hanson MB, Dill LM (2005) Factors influencing the diving behaviour of fish-eating killer whales: sex differences and diel and interannual variation in diving rates. Can J Zool 83:257-267

Barrett-Lennard LG (2000) Population structure and mating patterns of killer whales (Orcinus orca) as revealed by DNA analysis. PhD dissertation, University of British Columbia, Vancouver, BC

Beacham TD, Candy JR, Jonsen KL, Supernault J and others (2006) Estimation of stock composition and individual identification of Chinook salmon across the Pacific Rim by use of microsatellite variation. Trans Am Fish Soc 135: 861-888

Bigg M (1982) An assessment of killer whale (Orcinus orca) stocks off Vancouver Island, British Columbia. Rep Int Whaling Comm 32:655-666

Black N, Ternullo R, Schulman-Janiger A, Hammers AM, Stap P (2001) Occurrence, behavior, and photo-identification of killer whales in Monterey Bay, California. 14th Biennial Conference on the Biology of Marine Mammals. Society for Marine Mammology, Vancouver, BC, p 26

Blankenship S, Dean C, Hawkins D, Milward D, Von Bargen J, Warheit K (2009) Fisheries shaping to minimize impacts on stocks of concern using in-season genetic stock identification of encountered fish. Washington Department of Fish and Wildlife, Olympia, WA

Buhle ER, Holsman KK, Scheuerell MD, Albaugh A (2009) Using an unplanned experiment to evaluate the effects of hatcheries and environmental variation on threatened populations of wild salmon. Biol Conserv 142: 2449-2455

Bundy A (2001) Fishing on ecosystems: the interplay of fishing and predation in Newfoundland-Labrador. Can J Fish Aquat Sci 58:1153-1167

Candy JR, Irvine JR, Parken CK, Lemke SL, Bailey RE, Wetklo M, Jonsen K (2002) A discussion paper on possible new stock groupings (conservation units) for Fraser River Chinook salmon. Research Document 2002/085, Canadian Stock Assessment Secretariat, Ottawa, ON, available at www.dfo-mpo.gc.ca/csas/

Center for Whale Research (2008) Orca survey. Available at www.whaleresearch.com/orca_ID_matrilines.html

> Cullon DL, Yunker MB, Alleyne C, Dangerfield NJ, O'Neill S, Whiticar MJ, Ross PS (2009) Persistent organic pollutants in Chinook salmon (Oncorhynchus tshawytscha): implications for resident killer whales of British Columbia and adjacent waters. Environ Toxicol Chem 28:148-161

DFO (Fisheries and Oceans Canada) (2003) State of the Eastern Scotian Shelf ecosystem. Ecosystem Status Report 2003/004. DFO, Canadian Science Advisory Secretariat, Ottawa, ON, available at www.dfo-mpo.gc.ca/csas/

DFO (2008) Recovery strategy for the northern and southern resident killer whales (Orcinus orca) in Canada. Fisheries and Oceans Canada, Ottawa, ON

English KK, Bailey RE, Robichaud D (2007) Assessment of Chinook salmon returns to the Fraser River watershed using run reconstruction techniques, 1982-04. Research Document 2007/020, Canadian Science Advisory Secretariat, Ottawa, ON, available at www.dfo-mpo.gc.ca/csas/

Felleman FL, Heimlich-Boran JR, Osborne RW (1991) Feeding ecology of the killer whale (Orcinus orca). In: Pryor K, Norris KS (eds) Dolphin societies. University of California Press, Berkeley, CA, p 113-147

Ford JKB, Ellis GM (2006) Selective foraging by fish-eating killer whales Orcinus orca in British Columbia. Mar Ecol
Prog Ser 316:185-199

Ford JKB, Ellis GM, Barrett-Lennard LG, Morton AB, Palm RS, Balcomb KC III (1998) Dietary specialization in two sympatric populations of killer whales (Orcinus orca) in coastal British Columbia and adjacent waters. Can J Zool $76: 1456-1471$

Ford JKB, Ellis GM, Balcomb KC (2000) Killer whales: the natural history and genealogy of Orcinus orca in British Columbia and Washington State, 2nd edn. University of British Columbia Press, Vancouver, BC

Ford JKB, Ellis GM, Olesiuk PF, Balcomb KC III (2009) Linking killer whale survival and prey abundance: Food limitation in the oceans' apex predator? Biol Lett doi:10. 1098/rsbl.2009.0468

> Guenette S, Heymans SJJ, Christensen V, Trites AW (2006) Ecosystem models show combined effects of fishing, predation, competition, and ocean productivity on Steller sea lions (Eumetopias jubatus) in Alaska. Can J Fish Aquat Sci 63:2495-2517

Hauser DDW (2006) Summer space use of southern resident killer whales (Orcinus orca) within Washington and British Columbia inshore waters. MS thesis, University of Washington, Seattle, WA

Hauser DDW, Logsdon MG, Holmes EE, VanBlaricom GR, Osborne RW (2007) Summer distribution patterns of southern resident killer whales Orcinus orca: core areas and spatial segregation of social groups. Mar Ecol Prog Ser 351:301-310

Healey MC (1991) The life history of Chinook salmon (Oncorhynchus tshawytscha). In: Groot C, Margolis L (eds) Life history of Pacific salmon. University of British Columbia Press, Vancouver, BC, p 311-349

Healey MC, Groot C (1987) Marine migration and orientation of ocean-type Chinook and sockeye salmon. Am Fish Soc Symp 1:298-312

Heimlich-Boran JR (1986) Fishery correlations with the occurrence of killer whales in greater Puget Sound. In: Kirkevold B, Lockhard J (eds) Behavioral biology of killer whales. AR Liss, New York, p 113-131

Heimlich-Boran JR (1988) Behavioral ecology of killer whales (Orcinus orca) in the Pacific Northwest. Can J Zool 66: 565-578

Hoelzel AR (1993) Foraging behaviour and social group dynamics in Puget Sound killer whales. Anim Behav 45: 581-591

- Hoelzel AR, Natoli A, Dahlheim ME, Olavarria C, Baird RW, Black NA (2002) Low worldwide genetic diversity in the killer whale (Orcinus orca): implications for demographic history. Proc R Soc Lond B Biol Sci 269: $1467-1473$

Hoelzel AR, Hey J, Dahlheim ME, Nicholson C, Burkanov V, Black N (2007) Evolution of population structure in a highly social top predator, the killer whale. Mol Biol Evol 24:1407-1415

> Holt MM, Noren D, Viers V, Emmons C, Viers S (2009) Speaking up: killer whales (Orcinus orca) increase their call amplitude in response to vessel noise. J Acoust Soc Am 125:EL27-EL32

Holtby LB, Ciruna KA (2007) Conservation units for Pacific Salmon under the Wild Salmon Policy. Research Document 2007/070, Canadian Science Advisory Secretariat, Ottawa, ON, available at www.dfo-mpo.gc.ca/csas/

Jearld A (1983) Age determination. In: Nielsen LA, Johnson DL (eds) Fisheries techniques. American Fisheries Society, Bethesda, MD, p 301-324

Krahn MM, Wade PR, Kalinowski ST, Dahlheim ME and others (2002) Status review of Southern Resident killer 
whales (Orcinus orca) under the Endangered Species Act. NOAA Tech Memo NMFS-NWFSC-54, Northwest Fisheries Science Center, Seattle, WA

Krahn MM, Ford MJ, Perrin WF, Wade PR and others (2004) 2004 Status review of southern resident killer whales (Orcinus orca) under the Endangered Species Act. NOAA Tech Memo NMFS-NWFSC-62, Northwest Fisheries Science Center, Seattle, WA

Krahn MM, Hanson MB, Schorr GS, Emmons CK and others (2009) Effects of age, sex and reproductive status on persistent organic pollutant concentrations in 'southern resident' killer whales. Mar Pollut Bull 58:1522-1529

Lusseau D, Bain DE, Williams R, Smith JC (2009) Vessel traffic disrupts the foraging behavior of southern resident killer whales Orcinus orca. Endang Species Res 6: 211-221

Marshall AR, Miller M, Busack C, Phelps SR (1991) Genetic stock identification analysis of three 1990 Washington Ocean and Strait of Juan de Fuca Chinook salmon fisheries. GSI Summary Report 91-1, Washington Department of Fisheries, Salmon Research and Development, Olympia, WA

Matkin DR, Dahlheim ME (1995) Feeding behaviors of killer whales in northern southeastern Alaska. In: Endstrom DR (ed) Proceedings of the Third Glacier Bay Science Symposium, 15-18 Sep 1993. US Department of the Interior, National Park Service, Anchorage, AK, p 246-253

Matkin CO, Barrett-Lennard LG, Yurk H, Ellifrit D, Trites AW (2007) Ecotypic variation and predatory behavior among killer whales (Orcinus orca) off the eastern Aleutian Islands, Alaska. Fish Bull 105:74-87

McCluskey SM (2006) Population trends and movement complexity patterns of southern resident killer whales (Orcinus orca) in relation to Pacific salmon (Oncorhynchus spp.) in the inland waters of Washington State and British Columbia. MS thesis, University of Washington, Seattle, WA

Mobrand LE, Barr J, Blankenship L, Campton DE and others (2005) Hatchery reform in Washington State: principles and emerging issues. Fisheries 30:11-33

Myers JM, Kope RG, Bryant GJ, Teel D and others (1998) Status review of Chinook salmon from Washington, Idaho, Oregon and California. NOAA Tech Memo NMFSNWFSC-35, Northwest Fisheries Science Center, Seattle, WA

Neaves PI, Wallace CG, Candy JR, Beacham TD (2005) cBayes: computer program for mixed stock analysis of allelic data. Version 3.0. Available at www.pac.dfompo.gc.ca/sci/mgl/Cbayes_e.htm

NMFS (National Marine Fisheries Service) (1997) Impacts of California sea lions and Pacific harbor seals on salmonids and on the coastal ecosystems of Washington, Oregon, and California. NOAA Tech Memo NMFS-NWFSC-28, Northwest Fisheries Science Center, Seattle, WA

NMFS (2005) Endangered and threatened species: final listing determinations for 16 ESUs of West Coast salmon, and final 4(d) protective regulations for threatened salmonid ESUs. Fed Regist 70:37160-37204, available at www.nwr.noaa.gov/Publications/FR-Notices/2005/upload/ 70FR37160.pdf

NMFS (2008a) Endangered Species Act: Section 7. Formal consultation biological opinion. Effects of the 2008 Pacific Coast salmon plan fisheries on the southern resident killer whale distinct population segment (Orcinus orca) and their critical habitat. National Marine Fisheries Service, available at https://pcts.nmfs.noaa.gov/pls/pctspub/pcts_upload.summary_list_biop?p_id=107757
NMFS (2008b) Recovery plan for southern resident killer whales (Orcinus orca). National Marine Fisheries Service, Northwest Region, Seattle, WA, available at www.nwr.noaa.gov/Marine-Mammals/Whales-DolphinsPorpoise/Killer-Whales/ESA-Status/Orca-RecoveryPlan.cfm

NMFS (2009) Biological opinion and conference opinion on the long-term operations of the Central Valley Project and State Water Project. NMFS Tracking No. 2008/09022, National Marine Fisheries Service, Southwest Region, available at http://swr.nmfs.noaa.gov/ocap.htm

Noren D, Johnson A, Rehder D, Larson A (2009) Close approaches by vessels elicit surface active behaviors by southern resident killer whales. Endang Species Res 8: 179-192

Osborne R (1999) A historical ecology of Salish Sea resident killer whales (Orcinus orca), with implications for management. PhD dissertation. University of Victoria, Victoria, $\mathrm{BC}$

Pacific Fishery Management Council (2009) Review of 2008 ocean salmon fisheries. Pacific Fishery Management Council, Portland, OR

Parken CK, Candy JR, Irvine JR, Beacham TD (2008) Genetic and coded wire tag results combine to allow more-precise management of a complex Chinook salmon aggregate. $\mathrm{N}$ Am J Fish Manage 28:328-340

Pella J, Masuda M (2001) Bayesian methods for analysis of stock mixtures from genetic characters. Fish Bull 99: 151-167

Pitman RL, Perryman WL, Leroi D, Eilers E (2007) A dwarf form of killer whale in Antarctica. J Mammal 88:43-48

PSC (Pacific Salmon Commission) (2007) Pacific Salmon Commission Joint Chinook Technical Committee report. Annual report on catch, escapement, exploitation rate analysis and model calibration of Chinook salmon under Pacific Salmon Commission jurisdiction, 2006. Report TCCHINOOK (07)-1. Pacific Salmon Commission, Vancouver, BC, available at www.psc.org

PSC (Pacific Salmon Commission) (2008a) Report of the Fraser River Panel to the Pacific Salmon Commission on the 2004 Fraser River sockeye salmon fishing season. Pacific Salmon Commission, Vancouver, BC, available at www.psc.org

PSC (Pacific Salmon Commission) (2008b) The strategic plan of the Southern Fund Committee, Unpublished Report. Southern Boundary Restoration \& Enhancement Fund, Pacific Salmon Commission, Vancouver BC, available at www.psc.org

Purcell M, Mackey G, LaHood E, Huber H, Park L (2004) Molecular methods for the genetic identification of salmonid prey from Pacific harbor seal (Phoca vitulina richardsi) scat. Fish Bull 102:213-220

Raymond M, Rousset F (1995a) An exact test for population differentiation. Evolution 49:1280-1283

Raymond M, Rousset F (1995b) GENEPOP (version 1.2): population genetics software for exact tests and ecumenicism. J Hered 86:248-249

Roos JF (1991) Restoring Fraser River salmon: a history of the International Pacific Salmon Fisheries Commission 1937-1985. Pacific Salmon Commission, Vancouver, BC

Rousset F (2008) GENEPOP ‘ 007: a complete re-implementation of the GENEPOP software for Windows and Linux. Mol Ecol Resour 8:103-106

Seeb LW, Antonovich A, Banks AA, Beacham TD and others (2007) Development of a standardized DNA database for Chinook salmon. Fisheries 32:540-552 
Trites AW, Donnelly CP (2003) The decline of Steller sea lions (Eumetopias jubatus) in Alaska: a review of the nutritional stress hypothesis. Mammal Rev 33:3-28

Ward EJ, Holmes EE, Balcomb KC (2009) Quantifying the effects of prey abundance on killer whale reproduction. J Appl Ecol 46:632-640

Weise MJ, Harvey JT (2005) Impact of the California sea lion (Zalophus californianus) on salmon fisheries in Monterey Bay, California. Fish Bull 103:685-696

Weitkamp LA (2010) Marine distributions of Chinook salmon (Oncorhynchus tshawytscha) from the West Coast of North America determined by coded wire tag recoveries. Trans Am Fish Soc 139:147-170

Editorial responsibility: Giovanni Bearzi, Milan, Italy
Williams TM, Estes JA, Doak DF, Springer AM (2004) Killer appetites: assessing the role of predators in ecological communities. Ecology 85:3373-3384

Williams R, Bain DE, Smith JC, Lusseau D (2009) Effects of vessels on behaviour patterns of individual southern resident killer whales Orcinus orca. Endang Species Res 6: 199-209

Zamon JE, Guy TJ, Balcomb K, Ellifrit D (2007) Winter observations of southern resident killer whales (Orcinus orca) near the Columbia River plume during the 2005 spring Chinook salmon (Oncorhynchus tshawytscha) spawning migration. Northwest Nat 88: 193-198

Submitted: August 11, 2009; Accepted: December 7, 2009 Proofs received from author(s): March 6, 2010 